\title{
Inoculation of corn silage with Lactobacillus plantarum and Bacillus subtilis associated with amylolytic enzyme supply at feeding. 2. Growth performance and carcass and meat traits of lambs
}

\author{
Erika C. Lara*, Uly C. Bragiato, Carlos H.S. Rabelo, Juliana D. Messana, \\ Américo G.S. Sobrinho, Ricardo A. Reis
}

UNESP, São Paulo State University, Department of Animal Sciences, 14884-900, Jaboticabal, SP, Brazil

\section{A R T I C L E I N F O}

\section{Keywords:}

Amylase

Bacterial inoculant

Fatty acid

Feed intake

Starch

\begin{abstract}
A B S T R A C T
The objective of this research was to investigate the effects of inoculation of corn silage and dietary supplementation of amylolytic enzymes, and their interaction, on lamb growth performance and carcass and meat traits. Whole-crop corn forage was treated either with water (untreated) or with Lactobacillus plantarum MA $18 / 5 \mathrm{U}$ at $1 \times 10^{5} \mathrm{cfu} / \mathrm{g}$ fresh forage combined with Bacillus subtilis AT553098 at $1 \times 10^{5} \mathrm{cfu} / \mathrm{g}$ fresh forage (inoculated) and ensiled for $170 \mathrm{~d}$. Forty non-castrated Texel $\times$ Dorper male lambs were arranged in a randomized block design $(n=10)$ and then assigned to one of four diets, as follows: 1) untreated corn silage with no amylolytic enzyme supply (NI-NA); 2) untreated corn silage with amylolytic enzyme supply (NI-WA); 3) inoculated corn silage with no amylolytic enzyme supply (WI-NA); and 4) inoculated corn silage with amylolytic enzyme supply (WI-WA). $\alpha$-Amylase (602 dextrinizing units/kg of dry matter $(D M))$ was supplied to the lambs at total mixed ration delivery. Inoculation of corn silage increased $(P=0.003)$ both digestible energy (DE) and metabolizable energy (ME) intake by 1.4 and $1.2 \mathrm{MJ} / \mathrm{kg} \mathrm{DM}$, respectively, and also resulted in higher average daily gain (ADG; $P=0.023$ ) of lambs (233 vs. $212 \mathrm{~g} / \mathrm{d}$ in lambs fed NI diet). In contrast, dietary supplementation with amylolytic enzymes had no effect on the DM intake $(P=0.90)$ or ADG $(P=0.15)$ of lambs. Moreover, inoculation, enzyme supplementation, and their interaction had no significant effects on carcass traits $(P \geq 0.06)$, commercial cut yield $(P \geq 0.26)$, chemical composition of meat $(P \geq 0.13)$, and meat tenderness and color $(P \geq 0.11)$. In terms of the fatty acid composition of longissimus muscle, inoculation of corn silage increased concentrations of saturated fatty acids (SFA; $P=0.035$ ) from $46.2 \%$ to $47.6 \%$, and reduced concentrations of unsaturated fatty acids (UFA; $P=0.035$ ) from $53.8 \%$ to $52.5 \%$, compared to the NI diet. Inoculation also reduced the UFA:SFA ratio $(P=0.031)$ from 1.17 to 1.11 , a small but significant difference. Dietary supplementation with amylolytic enzymes did not alter $(P \geq 0.09)$ SFA, UFA, and polyunsaturated
\end{abstract}

\footnotetext{
Abbreviations: ADFom, acid detergent fiber expressed exclusive of residual ash; ADG, average daily gain; aNDFom, neutral detergent fiber assayed with a heat stable amylase and expressed exclusive of residual ash; BW, body weight; CCW, cold carcass weight; CCY, cold carcass yield; CFU, colony-forming units; CL, cooking loss; CLA, conjugated linoleic acid; CP, crude protein; DE, digestible energy; DM, dry matter; DMI, dry matter intake; DU, dextrinizing unit; EE, ether extract; FA, fatty acid; FFA, free fatty acid; GE, gross energy; HCW, hot carcass weight; HCY, hot carcass yield; LDL, low-density lipoprotein; LMA, longissimus muscle area; ME, metabolized energy; OM, organic matter; PUFA, polyunsaturated fatty acid; SFA, saturated fatty acid; TMR, total mixed ration; TN, total nitrogen; UFA, unsaturated fatty acid; VFA, volatile fatty acid; WBSF, Warner-Bratzler shear force; WHC, water-holding capacity

* Corresponding author at: Departamento de Zootecnia, Universidade Estadual Paulista (UNESP), Via de acesso Prof. Paulo Donato Castellane, km 5, 14884-900, Jaboticabal, SP, Brazil.

E-mail address: erika.lara@agroceres.com (E.C. Lara).
} 
fatty acid concentrations, or their ratios. In conclusion, our results indicated that the silage inoculant examined in the present study is recommended for use in improving lamb production at the farm scale, whereas inclusion of amylolytic enzymes is not required under our experimental conditions.

\section{Introduction}

Demand for animal products may double in developing countries by 2030 (FAO, 2015). Associated with this increased demand, consumers may play an important role in the meat production chain due to growing interest in how livestock diets can improve the meat quality of ruminants, thus promoting human health and disease prevention (Furnols et al., 2011; Scollan et al., 2006). As such, development of livestock management strategies that improve meat quality, such as the supplementation of ruminant diets, is essential. For instance, amylolytic enzymes are commonly used as direct-fed additives in order to improve starch utilization in highgrain diets (Nozière et al., 2014). In Brazil, this strategy is particularly important because hard-texture corn hybrids are mostly used, in which high vitreousness endosperms are predominant (Pereira et al., 2004). The vitreous endosperm possesses a continuous and abundant protein matrix, which limits the enzymatic digestion of starch and then reduces ruminal degradability of grains (Kotarski et al., 1992; Philippeau and Michalet-Doreau, 1997), compromising the total-tract starch digestibility (Bal et al., 1997). In this regard, dietary supplementation with amylolytic enzymes leads the starch hydrolysis by cleaving starch polymers to low molecular weight oligosaccharides. In turn, the availability of starch hydrolysis products might increase in the rumen, shifting the ruminal fermentation (e.g., increasing propionate) process with gains in digestibility and efficiency of dietary utilization (Tricarico et al., 2008). Improvements in digestibility of starch and other feed components (likely by cross-feeding effect) might result in increased dry matter intake (DMI), the way so that livestock production could be enhanced (Tricarico et al., 2008).

Furthermore, enhanced ruminal degradation of starch alters ruminal fermentation by increasing the molar proportion of propionate and concentrations of total volatile fatty acids (VFA; Church, 1993). Increased concentration of VFA (accounts for up 70\% of the energy requirements of ruminants) may result in higher gluconeogenesis due to metabolism of propionate in the liver, whereas a higher synthesis of long-chain fatty acids (FA) in adipose tissue is expected due to metabolism of acetate (Bergman, 1990; Ingle et al., 1972). Thereby, increasing total amount of VFA production might increase FA synthesis in adipose tissue. Although previous research has suggested that dietary supplementation with amylolytic enzymes have no effect on the carcass traits of lambs (McAllister et al., 2000; Prado et al., 2015), to the best our knowledge, meat quality and FA composition has not been appropriately examined in finishing feedlot lambs fed diets supplemented with amylolytic enzymes.

In addition to amylase supplementation, silage inoculants have been used to improve fermentation and aerobic stability of corn and other crops silages worldwide (Kung et al., 2003), so that the nutritional value of livestock diets could be improved as well. Regarding the silage inoculants, Lactobacillus plantarum, a facultative heterofermentative lactic acid bacterium, is the most common microorganism used to preserve the nutritional quality of ensiled forages by improving lactic acid fermentation and inhibiting deleterious epiphytic microbes (McDonald et al., 1991; Oliveira et al., 2017). Moreover, the Bacillus subtilis, a bacterium commonly found in the soil, was proposed to be used as a silage additive because of its potential to increase the aerobic stability of corn silage (Basso et al., 2012) by producing antifungal compounds (Zuber et al., 1993). The combination of the bacteria described above was tested in corn silage by Lara et al. (2016), who reported that inoculation improved silage digestibility. Improvements in corn silage preservation with gains in digestibility is particularly important because this feed is generally a component of the total mixed ration (TMR) used for livestock production in Brazil (Oliveira and Millen, 2014). Nevertheless, inoculation with Lactobacillus plantarum and Bacillus subtilis had no effect on dry matter intake (DMI) and average daily gain (ADG) of finishing feedlot beef cattle (Rabelo et al., 2018). However, to date few studies have focused on the effects of silage inoculation with these bacteria on the performance of livestock, and to the best of our knowledge there have been no studies on the effects of silage inoculation with these bacteria on meat quality.

It was hypothesized that both inoculation of corn silage and dietary supplementation with amylolytic enzyme could be used to manipulate feed utilization in order to improve performance and meat traits of lambs. As such, the objective of the current study was to examine the effects of bacterial inoculation of corn silage and dietary supplementation with amylolytic enzymes, and their interaction, on the growth performance and carcass and meat traits of lambs.

\section{Material and methods}

\subsection{Ethics statement}

Animal care and handling procedures were carried out in accordance with the Brazilian College of Animal Experimentation (COBEA) guidelines and were approved by the Ethics, Bioethics, and Animal Welfare Committee (CEBEA) of the FCAV/UNESPJaboticabal campus, Brazil (protocol no. 1.754/15).

\subsection{Crop harvest and silage preparation}

A flint corn (hybrid 2B710, Dow AgroSciences Cravinhos, SP, Brazil) was planted on December 18, 2013, on the grounds of São 
Paulo State University ( $21^{\circ} 15^{\prime} \mathrm{S}, 48^{\circ} 18^{\prime} \mathrm{W}$; altitude: $615 \mathrm{~m}$; Jaboticabal, SP, Brazil). On March 24, 2014 (97 d after planting), wholecrop corn was harvested in random locations throughout the field, at approximately $344 \mathrm{~g} / \mathrm{kg}$ dry matter (DM) and a stubble height of $20 \mathrm{~cm}$, using a pull-type JF $90^{\circledR}$ forage harvester (JF Agricultural Machinery, Itapira, SP, Brazil). Forage was cut to 10 mm; kernels were not processed. Thereafter, chopped forages were tractor loaded for delivery to the stack silos. Prior to ensiling, corn forage was treated either with water $\left(2 \mathrm{l} / \mathrm{t}\right.$; untreated) or with Lactobacillus plantarum MA $18 / 5 \mathrm{U}$ at $1 \times 10^{5}$ colony forming units (cfu)/g fresh forage (Lallemand Animal Nutrition, Goiânia, GO, Brazil) combined with Bacillus subtilis AT553098 at $1 \times 10^{5} \mathrm{cfu} / \mathrm{g}$ fresh forage (inoculated; Fatec Animal Nutrition and Health, Arujá, SP, Brazil). The inoculant was dissolved in distilled water ( $21 / \mathrm{t}$ ) and sprayed directly onto fresh forage as the silos were filled. Application levels were verified by dilution plating on Man, Rogosa, and Sharpe agar

Table 1

Ingredient proportions, chemical composition, and fatty acid profiles of the total mixed rations containing untreated corn silage or corn silage inoculated with Lactobacillus plantarum and Bacillus subtilis ${ }^{\mathrm{a}}$.

\begin{tabular}{|c|c|c|}
\hline Item & Untreated & Inoculated \\
\hline \multicolumn{3}{|l|}{ Ingredient proportions, $\mathrm{g} / \mathrm{kg}$ DM } \\
\hline Corn silage & 400 & 400 \\
\hline Ground corn & 480 & 480 \\
\hline Urea & 12.0 & 12.0 \\
\hline Soybean meal & 84.0 & 84.0 \\
\hline Comercial premix ${ }^{\mathrm{b}}$ & 24.0 & 24.0 \\
\hline \multicolumn{3}{|l|}{ Chemical composition, $\mathrm{g} / \mathrm{kg}$ DM } \\
\hline $\mathrm{DM}^{\mathrm{c}}$ & 669 & 675 \\
\hline $\mathrm{OM}$ & 943 & 948 \\
\hline $\mathrm{CP}$ & 151 & 150 \\
\hline $\mathrm{EE}$ & 21.0 & 20.0 \\
\hline Starch & 371 & 363 \\
\hline aNDFom & 257 & 258 \\
\hline ADFom & 126 & 126 \\
\hline \multicolumn{3}{|l|}{ Fatty acid profile, $\%$} \\
\hline C12:0 (lauric) & 0.29 & 0.33 \\
\hline C14:0 (myristic) & 0.32 & 0.37 \\
\hline C15:0 (pentatonic) & 0.06 & 0.06 \\
\hline C16:0 (palmitic) & 16.9 & 16.0 \\
\hline C16:1 (palmitoleic) & 0.20 & 0.20 \\
\hline C17:0 (heptadecanoic) & 0.23 & 0.33 \\
\hline C17:1 (cis-10-heptadecenoic) & 0.11 & 0.14 \\
\hline C18:0 (stearic) & 3.06 & 3.05 \\
\hline C18:1 n-7 (vaccenic) & 1.06 & 1.45 \\
\hline C18:1 n-9 (oleic) & 28.9 & 28.7 \\
\hline C18:2 n-6 (linoleic) & 41.6 & 40.8 \\
\hline C18:3 n-3 (linolenic) & 0.20 & 0.16 \\
\hline C18:3 n-6 ( $\gamma$-linolenic) & 4.93 & 6.33 \\
\hline C20:0 (arachidic) & 0.78 & 0.77 \\
\hline C20:1 n-9 (5-eicosanoic) & 0.37 & 0.36 \\
\hline C22:0 (docosanoic) & 0.37 & 0.34 \\
\hline C23:0 (tricosaenoic) & 0.10 & 0.07 \\
\hline C24:0 (lignoceric) & 0.52 & 0.49 \\
\hline $\mathrm{SFA}^{\mathrm{d}}$ & 22.6 & 21.8 \\
\hline $\mathrm{UFA}^{\mathrm{e}}$ & 77.4 & 78.2 \\
\hline MUFA $^{f}$ & 30.6 & 30.9 \\
\hline PUFA $^{g}$ & 46.7 & 47.3 \\
\hline
\end{tabular}

${ }^{a}$ Whole-crop corn forage was treated at ensiling either with distilled water $(2 \mathrm{~L} / \mathrm{t}$; untreated) or with Lactobacillus plantarum MA 18/5U at $1 \times 10^{5} \mathrm{cfu} / \mathrm{g}$ fresh forage (Lallemand Animal Nutrition, Goiânia, GO, Brazil) and Bacillus subtilis AT553098 at $1 \times 10^{5} \mathrm{cfu} / \mathrm{g}$ fresh forage (inoculated; Fatec Animal Nutrition and Health, Arujá, SP, Brazil).

b Commercial premix was composed (on a DM basis) of $7.0 \mathrm{~g} / \mathrm{kg} \mathrm{NaCl} ; 7.0 \mathrm{~g} / \mathrm{kg}$ phosphate; $25.6 \mathrm{~g} / \mathrm{kg}$ limestone; $12 \mathrm{~g} / \mathrm{kg} \mathrm{Ca} ; 4.0 \mathrm{~g} / \mathrm{kg} \mathrm{P} ; 2.85 \mathrm{~g} / \mathrm{kg} \mathrm{Na} ; 4.49 \mathrm{~g} / \mathrm{kg} \mathrm{Cl} ; 6.35 \mathrm{~g} / \mathrm{kg} \mathrm{K} ; 1.44 \mathrm{~g} / \mathrm{kg} \mathrm{Mg} ; 1.79 \mathrm{~g} / \mathrm{kg} \mathrm{S}$; $131 \mathrm{mg} / \mathrm{kg}$ Fe; $0.78 \mathrm{mg} / \mathrm{kg}$ Co; $0.42 \mathrm{mg} / \mathrm{kg}$ Se; $42 \mathrm{mg} / \mathrm{kg}$ vitamin E; 5799 UI vitamin A; and 501 UI vitamin D3.

${ }^{c} \mathrm{DM}=$ dry matter; $\mathrm{OM}=$ organic matter; $\mathrm{CP}=$ crude protein; $\mathrm{EE}=$ ether extract; aNDFom $=$ neutral detergent fiber assayed with a heat stable amylase and expressed exclusive of residual ash; $\mathrm{ADF}$ m $=$ acid detergent fiber expressed exclusive of residual ash.

${ }^{\mathrm{d}}$ Saturated fatty acids $=$ C12:0, C14:0, C15:0, C16:0, C18:0, C20:0, C22:0, C23:0, and C24:0.

e Unsaturated fatty acids $=$ C16:1, C17:1 cis-10, C17:1, C18:1 n-9, C18:1 n-7, C18:2 n-6, C18:3 n-3, C18:3 n-6, and C20:1 $n-9$.

${ }^{\mathrm{f}}$ Monounsaturated fatty acids $=\mathrm{C} 16: 1, \mathrm{C} 17: 1$ cis-10, C17:1, C18:1 n-9, C18:1 n-7, and C20:1 n-9.

g Polyunsaturated fatty acids $=\mathrm{C} 18: 2 n-6, \mathrm{C} 18: 3 n-3$, and C18:3 $n-6$. 
(MRS, Oxoid Ltd., Unipath, Basingstoke, UK), and were determined in accordance with protocols used in previous studies carried out in our laboratory (Basso et al., 2012, 2014; Lara et al., 2016).

Two stack silos ( $n=1$ silo per treatment) were each filled with approximately 20 tons corn forage (fresh matter) over two consecutive days. To avoid possible cross-contamination, untreated forage was ensiled first, followed by inoculated forage. Forage was packed by a wheel launder (Cat, Peoria, Chicago, USA), and the average bulk density in the silos was calculated to be $580 \mathrm{~kg}$ fresh forage $/ \mathrm{m}^{3}$ by the end of filling. Silos were sealed with black-on-white polyethylene film (thickness 200- $\mu \mathrm{m}$; Electro Plastic, São Paulo, SP, Brazil), which was weighted down with soil to ensure close contact between the film cover and the surface of the silage. Silos were stored in the field (ambient temperature $22.1 \pm 2.5^{\circ} \mathrm{C}$ ) for $170 \mathrm{~d}$. The silage was removed from the silo face using a fork in a feedout rate of approximately $10.0 \pm 4.0 \mathrm{~cm} / \mathrm{d}$. Ten fresh samples $(\sim 300 \mathrm{~g})$ of corn forage were collected from each silo during filling and stored at $-20^{\circ} \mathrm{C}$ until further analysis.

\subsection{Aerobic stability}

An aerobic stability assay was carried out during feed-out as follows. Six silage samples $(\sim 3 \mathrm{~kg})$ from each farm silo were placed in plastic buckets of 51 capacity and kept at ambient temperature. The silage temperature was measured every half hour by a datalogger placed in the centre of the mass for $5 \mathrm{~d}$. The ambient temperature was also measured every half hour by two dataloggers distributed near the buckets. Aerobic stability was defined as the number of hours that the silage temperature remained stable before increasing $2^{\circ} \mathrm{C}$ above the ambient temperature (Moran et al., 1996).

\subsection{Animal management and feeding}

After silos were opened, silages described above were used to formulate four TMR daily, as follow: 1) untreated corn silage with no amylolytic enzyme supply (NI-NA); 2) untreated corn silage with amylolytic enzyme supply (NI-WA); 3) inoculated corn silage with no amylolytic enzyme supply (WI-NA); and 4) inoculated corn silage with amylolytic enzyme supply (WI-WA). Diets were composed of $400 \mathrm{~g} / \mathrm{kg}$ of treated or untreated corn silage and $600 \mathrm{~g} / \mathrm{kg}$ concentrate on a DM basis (Table 1), and balanced to meet the nutritional requirements of lambs projected to gain $300 \mathrm{~g} / \mathrm{d}$ (NRC, 2007). Feed ingredients (silage and concentrate) used to formulate the TMRs were sampled twice weekly to assess DM and for chemical analyses. Silage was obtained by sampling from six locations from the feeding face of each silo (two each from the lower and upper areas, and two from the center) and bulked into a single sample on each sampling day. Details about the chemical compositions of both the untreated and inoculated corn silages are presented in Lara et al. (2018). The DM of ingredients measured weekly was used to adjust the proportion of ingredients in the TMRs.

A powdered concentrate from A. oryzae (Amaize, Alltech Inc.) containing primarily $\alpha$-amylase activity was used in the current study; $\alpha$-amylase activity was determined according to the procedure described in the Food Chemicals Codex (1996). One $\alpha$-amylase dextrinizing unit (DU) was defined as the enzyme quantity required to dextrinize soluble starch at the rate of $1 \mathrm{~g} / \mathrm{h}$ at $30{ }^{\circ} \mathrm{C}$ and $\mathrm{pH}$ 4.8. The preparation used in the current study contained $301 \mathrm{DU} / \mathrm{g}$ of product. This preparation was added to TMR, under constant mixing by hand, immediately at the time of feeding delivery at a rate of $2 \mathrm{~g} / \mathrm{kg} \mathrm{DM}$; this process was repeated twice daily (07:00 and 16:00). Thus, the final concentration of $\alpha$-amylase fed to the lambs was $602 \mathrm{DU} / \mathrm{kg} \mathrm{DM}$.

Forty non-castrated male Texel $\times$ Dorper lambs (initial body weight $(\mathrm{BW})=23.9 \pm 4.7 \mathrm{~kg}$; age $=3$ months) were blocked by weight into 10 groups, with each lamb housed individually in $0.5 \mathrm{~m}^{2}$ wooden pens equipped with a feed bunk and a water bowl. Lambs were randomly assigned $(n=10)$ to one of the four diets, which they were fed twice daily (07:00 and 16:00) ad libitum (producing approximately 10\% orts), and given free access to drinking water. Approximately 60\% of the diet was offered at 07:00 and the remaining $40 \%$ at 16:00. A $15 \mathrm{~d}$ period was allocated for the lambs to adapt to the diets based on a previous study assessing the growth performance of lambs fed inoculated silage in our laboratory (Basso et al., 2014). Lambs were fed only corn silage for the first $3 \mathrm{~d}$ of the adaptation period, and thereafter concentrate was incorporated into the diet at $10 \%$ intervals over the three subsequent days until a forage:concentrate ratio of 40:60 was attained. The feeding program was carried out by $82 \mathrm{~d}$.

\subsection{Nutrient intake and growth performance}

The amount of feed offered was recorded daily; orts were weighed every morning, and samples of offered feed and orts were collected twice weekly and stored at $-20{ }^{\circ} \mathrm{C}$ for later analysis. Feed intake, ADG, and feed efficiency (expressed as gain per feed) were measured during the post-adaptation period (from $16 \mathrm{~d}$ until slaughter). The DM of the TMRs and the daily orts were used to calculate daily DMI for each lamb. The initial and final BW was measured at the beginning and at the end of the experimental period after a 16$\mathrm{h}$ fast. The ADG was calculated by subtracting initial BW from the final BW and dividing the difference by the time in which lambs remained in the trial. Lambs were weighed full every $15 \mathrm{~d}$ to programme the slaughter.

\subsection{Determination of carcass and meat traits}

\subsubsection{Slaughter, carcass trait data collection, and sampling procedures}

Lambs were slaughtered by cerebral concussion (TEC 10 PC) followed by jugular and carotid venesection when they reached a final BW of $35.0 \pm 1.8 \mathrm{~kg}$. Pre-harvest handling was in accordance with accepted animal welfare practices, and slaughtering procedures followed the Food of Animal Origin Sanitary and Industry Inspection (Brasil, 1997). Carcasses were split into two parts, and hot carcass weight (HCW) was recorded following removal of kidney, heart, and pelvic fat tissues. All carcasses were chilled for 
approximately $24 \mathrm{~h}$ at $4{ }^{\circ} \mathrm{C}$ and then re-weighed to determine the cold carcass weight (CCW). Hot carcass yield (HCY) and cold carcass yield (CCY) were calculated by dividing the HCW and CCW by fasted BW, respectively, and multiplying by 100 . The $12^{\text {th }}$ rib fat thickness (RFT) and $12^{\text {th }}$ rib longissimus muscle area (LMA) were measured on the left side of each carcass. The LMA was traced on transparencies and later measured with a planimeter, whereas RFT measurements were taken 3/4 the length ventrally over the longissimus muscle using a digital paquimeter (Greiner et al., 2003). Commercial cut yields were measured in the left half of each carcass by separating the carcass half into neck, shoulder, rib, loin, and leg sections.

After slaughter, initial $\mathrm{pH}$ was measured in the longissimus lumborum between the $12^{\text {th }}$ and $13^{\text {th }}$ ribs in the left half of the carcass of each lamb using a pH-meter with automatic endpoint and buffer recognition, as well as temperature compensation equipped with a penetrating electrode (Model Testo ${ }^{\circledast}$ 205, Testo-Direct Inc.). Final pH was recorded following $24 \mathrm{~h}$ post-mortem chilling of the carcass.

The longissimus muscle was removed completely from both the right (for use in physical-chemical analyses) and the left (for use in sensory analyses) sides of each carcass to estimate thawing and cooking losses (CL). These same samples were also used to assess the Warner-Bratzler shear force (WBSF). All longissimus muscle samples were vacuum-packaged and stored at $-20^{\circ} \mathrm{C}$ for $30 \mathrm{~d}$ prior to analyses.

\subsubsection{Color}

For the determination of meat color, a transversal cut was made through the longissimus muscle 30 min prior to readings to expose the myoglobin to oxygen (Cañeque and Sañudo, 2000). A Minolta Chroma Meter CR-400 colorimeter (Minolta Camera Co., Osaka, Japan) was used to measure the $L^{*} a^{*} b^{*}$ space; in this space, $L^{*}$ indicates brightness, and $a^{*}$ and $b^{*}$ represent the chromaticity coordinates, as follows: the axis that runs from $-a^{*}$ to $+a^{*}$ varies from green to red, and the axis that runs from $-b^{*}$ to $+b^{*}$ varies between blue and yellow. The colorimeter was calibrated against white and black standards prior to sample analysis. Readings were made in triplicate for each sample, and the average values of which were recorded.

\subsubsection{Steak thawing and cooking loss}

Steaks were thawed at $10^{\circ} \mathrm{C}$ in a BOD incubator for $12 \mathrm{~h}$ and oven-broiled in an electric oven at $175^{\circ} \mathrm{C}$, with the CL defined as the difference between the weight of the steaks before and after cooking.

\subsubsection{Warner-Bratzler shear force}

To determine the WBSF, internal temperatures of the steaks were monitored with a digital thermometer attached to a 20-gauge copper-constantan thermocouple (Omega Engineering, Stamford, CT) implanted in the center of each steak. When the internal temperature reached $35^{\circ} \mathrm{C}$, the steak was turned and allowed to reach an internal temperature of $71{ }^{\circ} \mathrm{C}$ before removal from the oven. The cooked WBSF steaks were cooled at room temperature. Six round cores $(1.27 \mathrm{~cm}$ diameter) were removed from each steak, and checked for visible fat and connective tissue, which if present were removed (Wheeler et al., 1995). Each core was sheared once perpendicularly to the fiber direction using a Warner-Bratzler shear machine of $1.016 \mathrm{~mm}$ at a speed of $300 \mathrm{~mm} / \mathrm{min}$ (Texture Analyser TAXT2i; Stable Micro Systems Ltd., Godalming, UK).

\subsubsection{Water-holding capacity}

To determine water-holding capacity (WHC), a $2 \mathrm{~g}$ steak sample was placed on filter paper between two acrylic plates, and a $10 \mathrm{~kg}$ weight was placed over the plates for 5 min (Honikel and Hamm, 1994); WHC was defined as the difference between the initial and final weights of the steaks (Hamm, 1986).

\subsubsection{Chemical composition of meat}

Samples used in the chemical analyses were lyophilized for $72 \mathrm{~h}$, following which samples were ground using a ball mill and analyzed for moisture, protein (AOAC, 1996; method no. 945.18), ether extract (EE) (AOAC, 1996; method no. 920.39), and ash (AOAC, 1996; method no. 923.03), in order to determine the chemical composition of each longissimus sample.

\subsubsection{Fatty acid profile}

Samples of the transversal section were collected from the longissimus muscle and freeze-dried and then frozen for subsequent lipid extraction and determination of free fatty acids (FFA). Lipids were extracted using a mixture of chloroform-methanol (Bligh and Dyer, 1959), and fatty acid methyl esters (FAME) were extracted following the ISO 5509 method (ISO, 1978) using n-hexane, methanol, and KOH. A mixed standard (C4-C24, Sigma-Aldrich, São Paulo, Brazil) was used to quantify individual fatty acids. Qualitative and quantitative measurements of fatty acid contents were performed with a Shimadzu gas chromatograph (Kyoto, Japan - Model GC-14B with a Communication Bus Module - CBM 102) equipped with a flame ionization detector (FID) and a fused silica capillary column (Omegawax 250, Sigma-Aldrich, São Paulo, Brazil). The column was $30 \mathrm{~m}$ in length, $0.25 \mathrm{~mm}$ in diameter, and film thickness was $0.25 \mu \mathrm{m}$ (Supelco SP-24136, Sigma-Aldrich, São Paulo, Brazil). Helium was used as the carrier gas at a flow rate of $1 \mathrm{ml} / \mathrm{min}$. Fatty acid analyses were performed via autoinjection of $1 \mu \mathrm{L}$ of each sample at a "split" at a division ratio of $1: 100$ and temperature of $250{ }^{\circ} \mathrm{C}$. The temperature of the oven was programmed to remain at $100^{\circ} \mathrm{C}$ for 2 min and then increase to $220^{\circ} \mathrm{C}$ at $4{ }^{\circ} \mathrm{C} / \mathrm{min}$ intervals for $25 \mathrm{~min}$, with the detector maintained at $280^{\circ} \mathrm{C}$. Identification and quantification of the fatty acid methyl esters was accomplished through comparison of retention times and concentrations with those of fatty acid methyl esters in the standard. The total relative amount of FFA was quantified by summing the peak area of each FFA, which accounted for 100\%; no internal standard were used with samples (Lage et al., 2014). 


\subsection{Chemical analyses}

Samples of forage and silage from the stack silos, and samples of feed ingredients, orts, and feces from the feeding experiment, were oven-dried at $55^{\circ} \mathrm{C}$ for $72 \mathrm{~h}$ and processed in a knife mill (Wiley Mill Model 4; Arthur H. Thomas Company, Philadelphia, PA), then ground through a $1 \mathrm{~mm}$ screen and analyzed for DM $\left(105^{\circ} \mathrm{C}\right.$ for $\left.12 \mathrm{~h}\right)$ and ash $\left(500{ }^{\circ} \mathrm{C}\right.$ for $\left.5 \mathrm{~h}\right)$ content, following the procedures described by the AOAC (1996. Organic matter (OM; $\mathrm{g} / \mathrm{kg}$ ) was calculated as 1000 - ash. Ether extract was also determined following the procedures described by the AOAC (1996. Total nitrogen (TN) was measured by rapid combustion using a LECO analyzer (model F528 N, LECO Corp., St. Joseph, MI, USA), and crude protein (CP) was calculated as TN $\times 6.25$. Neutral detergent fiber (aNDFom) and acid detergent fiber (ADFom) levels were measured using an Ankom F57 filter bag in a fiber analyzer (ANKOM 2000, ANKOM Technologies, Macedon, NY, USA), in accordance with the procedures described by Mertens (2002) and the AOAC (1996, respectively. Measurements of aNDFom were performed using a heat-stable amylase without sodium sulphite; both aNDFom and ADFom were expressed exclusive of residual ash. Starch content was determined enzymatically (Bach Knudsen et al., 1987), and gross energy (GE) was determined with a bomb calorimeter (PARR 6200; Parr Instrument Company, Milone, IL). Finally, metabolizable energy (ME) was estimated as digestible energy (DE) $\times 0.82(\mathrm{NRC}, 1985)$.

\subsection{Statistical analyses}

Feed intake, growth performance, and carcass and meat trait data were analyzed using the MIXED procedure of SAS (v. 9.0; SAS Institute Inc., Cary, NC) in a randomized block design under a $2 \times 2$ factorial arrangement. Diet was considered a fixed effect, and lambs were considered as random effects. Data of feed intake, growth performance, and carcass and meat trait were analyzed using the following general model:

$$
Y_{i j k}=\mu+a_{i}+E_{j}+I_{k}+E I_{j k}+e_{i j k}
$$

where $Y_{i j k}=$ response variable; $\mu=$ overall mean; $a=$ effect of animal (block) $i ; E=$ effect of enzyme $j ; I=$ effect of inoculant $k$; $E I$ $=$ effect of interaction between enzyme $j$ and inoculant $k$; and $e_{i j k}=$ error term.

Homogeneity of the data was verified using the UNIVARIATE procedure of SAS (v. 9.0; SAS Institute Inc., Cary, NC). Data normality was verified by the test of Cramer-Von-Mises, and all percentage data were transformed to arcsin square root (x) in order to avoid non-normal distribution (Jaeger, 2008). Studentized residuals were plotted against the predicted values using the plot procedure to analyze data for outliers. Differences between diet means were determined using the PDIFF option of LSMEANS in SAS software, which is based on Fisher's F-protected least significant differences test. Significant differences were declared in cases where

Table 2

Feed intake, growth performance, and carcass traits of lambs fed diets containing untreated corn silage (NI) or corn silage inoculated with Lactobacillus plantarum and Bacillus subtilis (WI) associated with (WA) or without (NA) amylolytic enzymes at feeding.

\begin{tabular}{|c|c|c|c|c|c|c|c|c|}
\hline \multirow{2}{*}{$\begin{array}{l}\text { Inoculation }^{\mathrm{a}} \\
\text { Enzyme }^{\mathrm{b}}\end{array}$} & \multicolumn{2}{|l|}{ NI } & \multicolumn{2}{|l|}{ WI } & \multirow[t]{2}{*}{ SEM } & \multicolumn{3}{|c|}{$P$-value ${ }^{\mathrm{c}}$} \\
\hline & NA & WA & NA & WA & & I & $\mathrm{E}$ & $\mathrm{I} \times \mathrm{E}$ \\
\hline \multicolumn{9}{|c|}{ Intake of nutrients, $\mathrm{g} / \mathrm{d}$} \\
\hline $\mathrm{DM}^{\mathrm{d}}$ & 1,136 & 1,124 & 1,175 & 1,176 & 25.8 & 0.24 & 0.90 & 0.87 \\
\hline OM & 1,063 & 1,055 & 1,106 & 1,083 & 21.0 & 0.27 & 0.62 & 0.83 \\
\hline $\mathrm{CP}$ & 177 & 174 & 178 & 179 & 3.35 & 0.52 & 0.88 & 0.74 \\
\hline $\mathrm{EE}$ & 25.0 & 23.0 & 23.0 & 23.0 & 0.45 & 0.36 & 0.73 & 0.25 \\
\hline aNDFom & 250 & 240 & 272 & 261 & 7.02 & 0.019 & 0.25 & 0.93 \\
\hline \multicolumn{9}{|c|}{ Growth performance and carcass traits } \\
\hline Initial $\mathrm{BW}, \mathrm{kg}$ & 20.6 & 20.3 & 20.3 & 20.2 & 0.69 & 0.14 & 0.30 & 0.56 \\
\hline Final BW, kg & 35.6 & 36.1 & 35.7 & 35.4 & 0.18 & 0.48 & 0.79 & 0.20 \\
\hline$A D G, g / d$ & 213 & 210 & 244 & 221 & 0.005 & 0.023 & 0.15 & 0.26 \\
\hline Feed efficiency & 0.187 & 0.196 & 0.205 & 0.193 & 0.004 & 0.36 & 0.82 & 0.21 \\
\hline $\mathrm{HCW}, \mathrm{kg}$ & 17.0 & 17.2 & 17.1 & 16.9 & 0.11 & 0.63 & 0.85 & 0.45 \\
\hline CCW, kg & 16.6 & 16.7 & 16.7 & 16.3 & 0.11 & 0.50 & 0.65 & 0.30 \\
\hline $\mathrm{HCY}, \%$ & 48.9 & 47.3 & 47.9 & 47.7 & 0.24 & 0.45 & 0.059 & 0.13 \\
\hline CCY, \% & 47.0 & 45.8 & 46.7 & 46.3 & 0.29 & 0.87 & 0.17 & 0.47 \\
\hline $\mathrm{RFT}, \mathrm{mm}$ & 4.20 & 3.70 & 3.60 & 3.60 & 0.20 & 0.36 & 0.50 & 0.47 \\
\hline LMA, $\mathrm{cm}^{2}$ & 14.8 & 14.5 & 14.2 & 13.3 & 0.33 & 0.18 & 0.39 & 0.67 \\
\hline
\end{tabular}

${ }^{a}$ Whole-crop corn forage was treated at ensiling either with distilled water (2 L/t; untreated) or with Lactobacillus plantarum MA $18 / 5 \mathrm{U}$ at $1 \times 10^{5} \mathrm{cfu} / \mathrm{g}$ fresh forage (Lallemand Animal Nutrition, Goiânia, GO, Brazil) and Bacillus subtilis AT553098 at $1 \times 10^{5} \mathrm{cfu} / \mathrm{g}$ fresh forage (inoculated; Fatec Animal Nutrition and Health, Arujá, SP, Brazil).

${ }^{\mathrm{b}} \alpha$-amylase (602 DU/kg DM) was supplied to the wethers at total mixed ration delivery.

${ }^{\mathrm{c}} \mathrm{I}=$ inoculation; $\mathrm{E}=$ amylolytic enzymes; $\mathrm{I} \times \mathrm{E}=$ interaction between inoculation and amylolytic enzymes.

${ }^{\mathrm{d}} \mathrm{DM}=$ dry matter; $\mathrm{OM}=$ organic matter; $\mathrm{CP}=$ crude protein; $\mathrm{EE}=$ ether extract; aNDFom = neutral detergent fiber assayed with a heat stable amylase and expressed exclusive of residual ash; BW = body weight; ADG = average daily gain; HCW = hot carcass weight; CCW = cold carcass weight; $\mathrm{HCY}=$ hot carcass yield; CCY = cold carcass yield; RFT = rib fat thickness; LMA = Longissimus muscle area. 
$P \leq 0.05$, and discussion of trends was considered in cases where $0.05>P \leq 0.10$.

\section{Results}

\subsection{Aerobic stability of corn silage}

Inoculation of whole-crop corn silage increased the aerobic stability from $21.3 \pm 6.72 \mathrm{~h}$ in the untreated silage to $35.5 \pm 1.02 \mathrm{~h}$.

\subsection{Feed intake, growth performance and carcass traits}

Lambs fed the WI diet consumed $21.5 \mathrm{~g} / \mathrm{d}$ aNDFom more $(P=0.019)$ than those fed the NI diet $(245 \mathrm{~g} / \mathrm{d})$, but the DMI was unaffected $(P \geq 0.24)$ by the treatments (Table 2$)$. In addition, lambs fed the WI diet had higher ADG $(P=0.023)$ than those fed the NI diet ( 233 vs. $212 \mathrm{~g} / \mathrm{d})$. Carcass traits were unaffected $(P \geq 0.06)$ by inoculation, enzyme supplementation, and their interaction.

\subsection{Chemical composition of longissimus muscle}

Moisture, ash, CP, and EE contents in the longissimus muscle of lambs were not affected ( $P \geq 0.13$ ) by inoculation, enzyme supplementation, or their interaction (Table 3).

\subsection{Commercial cut weight and yield}

An interaction effect $(P=0.037)$ between inoculation and dietary supplementation with enzymes was detected for leg weight, with lambs fed the WI-WA diet having lower average leg weight, but no differences were detected for the lambs fed the NI-NA diet (Table 4). Inoculation and enzyme supplementation had no effects $(P \geq 0.16)$ on the other parameters pertaining to commercial cut weight and yield.

\subsection{Meat traits and color}

Values of WBSF were similar ( $P \geq 0.62$ ) between lambs fed the different diets (overall mean of $3 \mathrm{kgf}$ ). Other parameters concerning meat traits and color were also unaffected $(P \geq 0.09)$ by inoculation, enzyme supplementation, and their interaction (Table 5).

\subsection{Fatty acid profile of longissimus muscle}

Inoculation of corn silage increased $(P=0.023)$ the concentration of pentatonic acid in the longissimus muscle $(0.265 \%$ vs. $0.240 \%$ for lambs fed the US diet; Table 6$)$. Lambs fed the WA diet had lower concentrations of arachidonic $(P=0.032 ; 1.51 \%$ vs. $1.18 \%)$ and docosatetraenoic acid $(P=0.029 ; 0.145 \%$ vs. $0.115 \%)$ than did lambs fed the NA diet. Inoculation also tended $(P=$ 0.09 ) to reduce oleic acid concentrations in lambs fed the NA diet, but not in lambs fed the WA diet. Other FFAs, including conjugated linoleic acid (CLA), were not affected $(P \geq 0.053)$ by treatments.

When compared with the NI diet, inoculation of corn silage was found to increase concentrations of saturated fatty acids (SFA) ( $P$ $=0.035 ; 46.2 \%$ vs. $47.6 \%)$ and reduce concentrations of unsaturated fatty acids (UFA) $(P=0.035 ; 53.8 \%$ vs. $52.5 \%$; Table 7$)$. Inoculation also reduced the UFA:SFA ratio $(P=0.031 ; 1.17$ vs. 1.11). Moreover, there was an interaction effect between inoculation and enzyme supplementation $(P=0.009)$, in which enzyme supplementation enhanced elongase activity only in lambs fed the WI

Table 3

Chemical composition of longissimus muscle of lambs fed diets containing untreated corn silage (NI) or corn silage inoculated with Lactobacillus plantarum and Bacillus subtilis (WI) associated with (WA) or without (NA) amylolytic enzymes at feeding.

\begin{tabular}{|c|c|c|c|c|c|c|c|c|}
\hline \multirow{2}{*}{$\begin{array}{l}\text { Inoculation }^{\mathrm{a}} \\
\text { Enzyme }^{\mathrm{b}}\end{array}$} & \multicolumn{2}{|l|}{ NI } & \multicolumn{2}{|l|}{ WI } & \multirow[t]{2}{*}{ SEM } & \multicolumn{3}{|c|}{$P$-value ${ }^{\mathrm{c}}$} \\
\hline & NA & WA & NA & WA & & I & E & $\mathrm{I} \times \mathrm{E}$ \\
\hline Moisture & 74.5 & 74.0 & 73.1 & 74.9 & 0.45 & 0.77 & 0.48 & 0.19 \\
\hline Ash & 0.86 & 0.86 & 0.90 & 0.82 & 0.02 & 0.95 & 0.27 & 0.23 \\
\hline $\mathrm{CP}^{\mathrm{d}}$ & 22.4 & 23.1 & 23.5 & 22.0 & 0.36 & 0.96 & 0.56 & 0.13 \\
\hline $\mathrm{EE}$ & 2.22 & 2.07 & 2.47 & 2.26 & 0.11 & 0.30 & 0.40 & 0.89 \\
\hline
\end{tabular}

${ }^{a}$ Whole-crop corn forage was treated at ensiling either with distilled water ( $2 \mathrm{~L} / \mathrm{t}$; untreated) or with Lactobacillus plantarum MA $18 / 5 \mathrm{U}$ at $1 \times 10^{5} \mathrm{cfu} / \mathrm{g}$ fresh forage (Lallemand Animal Nutrition, Goiânia, GO, Brazil) and Bacillus subtilis AT553098 at $1 \times 10^{5} \mathrm{cfu} / \mathrm{g}$ fresh forage (inoculated; Fatec Animal Nutrition and Health, Arujá, SP, Brazil).

b $\alpha$-amylase (602 DU/kg DM) was supplied to the wethers at total mixed ration delivery.

c $\mathrm{I}$ = inoculation; $\mathrm{E}=$ amylolytic enzymes; $\mathrm{I} \times \mathrm{E}=$ interaction between inoculation and amylolytic enzymes.

${ }^{\mathrm{d}} \mathrm{CP}=$ crude protein; $\mathrm{EE}=$ ether extract. 
Table 4

Commercial cut weight and yield of lambs fed diets containing untreated corn silage (NI) or corn silage inoculated with Lactobacillus plantarum and Bacillus subtilis (WI) associated with (WA) or without (NA) amylolytic enzymes at feeding.

\begin{tabular}{|c|c|c|c|c|c|c|c|c|}
\hline \multirow{2}{*}{$\begin{array}{l}\text { Inoculation }^{\mathrm{a}} \\
\text { Enzyme }^{\mathrm{b}}\end{array}$} & \multicolumn{2}{|l|}{$\mathrm{NI}$} & \multicolumn{2}{|l|}{ WI } & \multirow[t]{2}{*}{ SEM } & \multicolumn{3}{|c|}{$P$-value ${ }^{\mathrm{c}}$} \\
\hline & NA & WA & NA & WA & & I & $\mathrm{E}$ & $\mathrm{I} \times \mathrm{E}$ \\
\hline \multicolumn{9}{|c|}{ Commercial cut, kg } \\
\hline Neck & 0.64 & 0.67 & 0.59 & 0.63 & 0.017 & 0.17 & 0.39 & 0.88 \\
\hline Shoulder & 1.83 & 1.83 & 1.82 & 1.74 & 0.020 & 0.29 & 0.34 & 0.34 \\
\hline Rib & 2.04 & 1.92 & 1.98 & 2.01 & 0.040 & 0.82 & 0.57 & 0.38 \\
\hline Loin & 1.06 & 1.09 & 1.04 & 1.01 & 0.018 & 0.16 & 0.95 & 0.34 \\
\hline Leg & $2.81^{\mathrm{xy}}$ & $2.85^{\mathrm{x}}$ & $2.85^{\mathrm{x}}$ & $2.68^{\mathrm{y}}$ & 0.026 & 0.17 & 0.18 & 0.037 \\
\hline \multicolumn{9}{|c|}{ Commercial cut yield, \% } \\
\hline Neck & 7.40 & 7.77 & 7.59 & 7.64 & 0.186 & 0.66 & 0.29 & 0.92 \\
\hline Shoulder & 21.9 & 21.8 & 22.3 & 21.6 & 0.209 & 0.79 & 0.39 & 0.45 \\
\hline Rib & 24.4 & 23.5 & 24.2 & 24.9 & 0.317 & 0.37 & 0.89 & 0.27 \\
\hline Loin & 12.7 & 13.0 & 12.5 & 12.5 & 0.147 & 0.26 & 0.68 & 0.58 \\
\hline Leg & 33.6 & 33.9 & 33.7 & 33.3 & 0.255 & 0.62 & 0.94 & 0.49 \\
\hline
\end{tabular}

${ }^{x-y}$ Means in the same row with different superscripts differed significantly ( $\left.P \leq 0.05\right)$.

${ }^{a}$ Whole-crop corn forage was treated at ensiling either with distilled water ( $2 \mathrm{~L} / \mathrm{t}$; untreated) or with Lactobacillus plantarum MA $18 / 5 \mathrm{U}$ at $1 \times 10^{5} \mathrm{cfu} / \mathrm{g}$ fresh forage (Lallemand Animal Nutrition, Goiânia, GO, Brazil) and Bacillus subtilis AT553098 at $1 \times 10^{5} \mathrm{cfu} / \mathrm{g}$ fresh forage (inoculated; Fatec Animal Nutrition and Health, Arujá, SP, Brazil).

b $\alpha$-amylase (602 DU/kg DM) was supplied to the wethers at total mixed ration delivery.

${ }^{c} \mathrm{I}=$ inoculation; $\mathrm{E}=$ amylolytic enzymes; $\mathrm{I} \times \mathrm{E}=$ interaction between inoculation and amylolytic enzymes.

\section{Table 5}

Meat traits of lambs fed diets containing untreated corn silage (NI) or corn silage inoculated with Lactobacillus plantarum and Bacillus subtilis (WI) associated with (WA) or without (NA) amylolytic enzymes at feeding.

\begin{tabular}{|c|c|c|c|c|c|c|c|c|}
\hline \multirow{2}{*}{$\begin{array}{l}\text { Inoculation }^{\mathrm{a}} \\
\text { Enzyme }^{\mathrm{b}}\end{array}$} & \multicolumn{2}{|l|}{$\mathrm{NI}$} & \multicolumn{2}{|l|}{ WI } & \multirow[t]{2}{*}{ SEM } & \multicolumn{3}{|c|}{$P$-value ${ }^{\mathrm{c}}$} \\
\hline & NA & WA & NA & WA & & I & $\mathrm{E}$ & $\mathrm{I} \times \mathrm{E}$ \\
\hline \multicolumn{9}{|l|}{ Meat traits } \\
\hline Initial $\mathrm{pH}$ & 6.50 & 6.50 & 6.60 & 6.50 & 0.030 & 0.094 & 0.52 & 0.64 \\
\hline Final pH & 5.60 & 5.50 & 5.70 & 5.70 & 0.038 & 0.13 & 0.48 & 0.86 \\
\hline $\mathrm{TL}, \%^{\mathrm{d}}$ & 4.20 & 4.80 & 5.00 & 4.60 & 0.295 & 0.60 & 0.89 & 0.47 \\
\hline CL, \% & 27.0 & 28.6 & 29.4 & 27.7 & 0.550 & 0.49 & 0.98 & 0.14 \\
\hline WHC, \% & 41.6 & 42.5 & 42.2 & 44.6 & 0.551 & 0.21 & 0.13 & 0.44 \\
\hline WBSF, kgf & 3.00 & 3.00 & 3.10 & 2.90 & 0.143 & 0.77 & 0.64 & 0.63 \\
\hline \multicolumn{9}{|l|}{ Meat color } \\
\hline $\mathrm{L}^{*}$ & 38.8 & 37.9 & 37.6 & 37.4 & 0.281 & 0.14 & 0.34 & 0.50 \\
\hline$a^{*}$ & 16.7 & 17.2 & 16.0 & 16.8 & 0.223 & 0.23 & 0.11 & 0.67 \\
\hline$b^{*}$ & 1.30 & 1.20 & 1.00 & 0.80 & 0.141 & 0.13 & 0.56 & 0.90 \\
\hline
\end{tabular}

${ }^{a}$ Whole-crop corn forage was treated at ensiling either with distilled water $(2 \mathrm{~L} / \mathrm{t}$; untreated) or with Lactobacillus plantarum MA $18 / 5 \mathrm{U}$ at $1 \times 10^{5} \mathrm{cfu} / \mathrm{g}$ fresh forage (Lallemand Animal Nutrition, Goiânia, GO, Brazil) and Bacillus subtilis AT553098 at $1 \times 10^{5} \mathrm{cfu} / \mathrm{g}$ fresh forage (inoculated; Fatec Animal Nutrition and Health, Arujá, SP, Brazil).

${ }^{\mathrm{b}} \alpha$-amylase (602 DU/kg DM) was supplied to the wethers at total mixed ration delivery.

${ }^{c} \mathrm{I}=$ inoculation; $\mathrm{E}=$ amylolytic enzymes; $\mathrm{I} \times \mathrm{E}=$ interaction between inoculation and amylolytic enzymes.

d $\mathrm{TL}=$ thawing loss; $\mathrm{CL}=$ cooking loss, $\mathrm{WHC}=$ water-holding capacity, WBSF $=$ Warner-Bratzler shear force; $\mathrm{L}^{*}=$ luminosity $(0=$ black, $100=$ white); $\mathrm{a}^{*}=$ index from green $(-)$ to red $(+) ; b^{*}=$ index from blue $(-)$ to yellow $(+)$.

diet. Other FA and enzymatic activity parameters analyzed were unaffected $(P \geq 0.09)$ in all treatments.

\section{Discussion}

The results of the current study showed that inoculation of corn silage with Lactobacillus plantarum and Bacillus subtilis increased the intake of aNDFom $(+8.8 \%)$. The increased aNDFom intake was due to a probable enhanced aNDFom digestibility caused by inoculation, which in turn likely arises from the higher aerobic stability of corn silage $(+14.2 \mathrm{~h}$ compared with the untreated silage). Bacillus subtilis is a bacterium known to produce antifungal compounds (Zuber et al., 1993), which results in lower yeast growth and lower silage deterioration (Basso et al., 2012). As silage deterioration reduces, there is an expected increase in digestibility because the nutritive value of silage is preserved of the action of spoilage microorganisms (Woolford, 1990). This was confirmed by Bolsen et al. (2000), who observed higher NDF and DM digestibility in diets composed of corn silage very well-fermented compared with those containing high level of spoilage. In our study with wethers (Lara et al., 2018), aNDFom digestibility increased following silage 
Table 6

Fatty acid profiles (\%) in the intramuscular fat of the longissimus muscle of lambs fed diets containing untreated corn silage (NI) or corn silage inoculated with Lactobacillus plantarum and Bacillus subtilis (WI) associated with (WA) or without (NA) amylolytic enzymes at feeding.

\begin{tabular}{|c|c|c|c|c|c|c|c|c|}
\hline \multirow{2}{*}{$\begin{array}{l}\text { Inoculation }^{\mathrm{a}} \\
\text { Enzyme }^{\mathrm{b}}\end{array}$} & \multicolumn{2}{|l|}{ NI } & \multicolumn{2}{|l|}{ WI } & \multirow[t]{2}{*}{ SEM } & \multicolumn{3}{|c|}{$P$-value ${ }^{c}$} \\
\hline & NA & WA & NA & WA & & I & $\mathrm{E}$ & $\mathrm{I} \times \mathrm{E}$ \\
\hline \multicolumn{9}{|l|}{ Saturated } \\
\hline C10:0 (capric) & 0.12 & 0.13 & 0.14 & 0.12 & 0.006 & 0.99 & 0.55 & 0.24 \\
\hline C12:0 (lauric) & 0.08 & 0.07 & 0.07 & 0.08 & 0.004 & 0.58 & 0.63 & 0.28 \\
\hline C14:0 (myristic) & 2.22 & 2.25 & 2.35 & 2.24 & 0.061 & 0.63 & 0.72 & 0.58 \\
\hline C15:0 (pentatonic) & 0.24 & 0.24 & 0.27 & 0.26 & 0.007 & 0.023 & 0.57 & 0.62 \\
\hline C16:0 (palmitic) & 25.2 & 26.1 & 26.2 & 26.4 & 0.190 & 0.11 & 0.15 & 0.36 \\
\hline C17:0 (heptadecanoic) & 0.89 & 0.93 & 0.89 & 0.92 & 0.019 & 0.86 & 0.32 & 0.94 \\
\hline C18:0 (stearic) & 16.5 & 17.2 & 17.2 & 16.7 & 0.310 & 0.87 & 0.83 & 0.37 \\
\hline C20:0 (arachidic) & 0.08 & 0.09 & 0.09 & 0.09 & 0.002 & 0.17 & 0.18 & 0.28 \\
\hline \multicolumn{9}{|l|}{ Monounsaturated } \\
\hline C14:1 (myristoleic) & 0.09 & 0.09 & 0.09 & 0.08 & 0.004 & 0.68 & 0.59 & 0.86 \\
\hline C16:1 (palmitoleic) & 1.45 & 1.52 & 1.60 & 1.40 & 0.042 & 0.88 & 0.45 & 0.13 \\
\hline C17:1 (c-10 heptadecenoic) & 0.51 & 0.50 & 0.50 & 0.50 & 0.012 & 0.73 & 0.92 & 0.88 \\
\hline C18:1 n-9 (oleic) & 42.0 & 41.4 & 40.2 & 41.3 & 0.246 & 0.051 & 0.56 & 0.090 \\
\hline C18:1 n-7 (vaccenic) & 2.76 & 2.61 & 2.60 & 2.53 & 0.060 & 0.27 & 0.33 & 0.73 \\
\hline C20:1 n-9 (5-eicosanoic) & 0.09 & 0.08 & 0.08 & 0.08 & 0.002 & 0.60 & 0.41 & 0.41 \\
\hline C24:1 n-9 (nervonic) & 0.20 & 0.16 & 0.17 & 0.15 & 0.008 & 0.19 & 0.090 & 0.47 \\
\hline \multicolumn{9}{|l|}{ Polyunsaturated } \\
\hline C18:2 n-6 (linoleic) & 4.60 & 4.20 & 4.71 & 4.31 & 0.136 & 0.70 & 0.16 & 0.99 \\
\hline C18:2 $c 9, t 11$ (CLA) ${ }^{\mathrm{d}}$ & 0.47 & 0.47 & 0.47 & 0.53 & 0.019 & 0.40 & 0.45 & 0.45 \\
\hline C18:3 n-6 ( $\gamma$-linolenic) & 0.07 & 0.06 & 0.07 & 0.06 & 0.003 & 0.85 & 0.29 & 0.61 \\
\hline C18:3 n-3 (linolenic) & 0.20 & 0.21 & 0.21 & 0.20 & 0.005 & 0.73 & 0.73 & 0.54 \\
\hline C20:2 (eicosadienoic) & 0.04 & 0.03 & 0.04 & 0.04 & 0.001 & 0.17 & 0.053 & 0.62 \\
\hline C20:3 n-6 (eicosatrienoic) & 0.15 & 0.12 & 0.13 & 0.12 & 0.006 & 0.35 & 0.10 & 0.30 \\
\hline C20:4 n-6 (arachidonic) & 1.67 & 1.21 & 1.35 & 1.15 & 0.075 & 0.21 & 0.032 & 0.38 \\
\hline C20:5 n-5 (eicosapentaenoic) & 0.05 & 0.04 & 0.05 & 0.06 & 0.005 & 0.38 & 0.90 & 0.35 \\
\hline C22:4 n-6 (docosatetraenoic) & 0.15 & 0.12 & 0.14 & 0.11 & 0.007 & 0.29 & 0.029 & 0.69 \\
\hline C22:6 n-3 (docosahexaenoic) & 0.03 & 0.02 & 0.03 & 0.02 & 0.002 & 0.54 & 0.13 & 0.68 \\
\hline
\end{tabular}

${ }^{a}$ Whole-crop corn forage was treated at ensiling either with distilled water ( $2 \mathrm{~L} / \mathrm{t}$; untreated) or with Lactobacillus plantarum MA $18 / 5 \mathrm{U}$ at $1 \times 10^{5} \mathrm{cfu} / \mathrm{g}$ fresh forage (Lallemand Animal Nutrition, Goiânia, GO, Brazil) and Bacillus subtilis AT553098 at $1 \times 10^{5} \mathrm{cfu} / \mathrm{g}$ fresh forage (inoculated; Fatec Animal Nutrition and Health, Arujá, SP, Brazil).

b $\alpha$-amylase (602 DU/kg DM) was supplied to the wethers at total mixed ration delivery.

${ }^{\mathrm{c}} \mathrm{I}=$ inoculation; $\mathrm{E}=$ amylolytic enzymes; $\mathrm{I} \times \mathrm{E}=$ interaction between inoculation and amylolytic enzymes.

${ }^{\mathrm{d}}$ CLA $=$ conjugated linoleic fatty acid.

inoculation. This result is in accordance with the findings of Rabelo et al. (2016a), who reported increased NDF intake $(+8.0 \%)$ in sheep fed TMR composed of inoculated corn silage. However, enhanced NDF digestibility often results in higher voluntary DMI due to the reduced gut fill (Allen, 1996), but this response was not observed. The diets used in this study were composed of corn silages with suitable composition (Kung et al., 2018) and likely lambs achieved satisfaction by energy demand instead repletion by physical distention in the gastrointestinal tract, which reflected in similar DMI. Indeed, there is a breakpoint in digestibility being that the DMI by physical fill in the gastrointestinal tract might be replaced by limitation by satisfaction of energy demand (Conrad et al., 1964).

Although inoculation resulted in increased aerobic stability of corn silage, the lack of a positive effect on DMI makes it difficult to account for the increased ADG ( $+9.9 \%)$ of lambs fed the WI diet. Enhanced ADG is often attributed to the increased feed intake or improved feed efficiency; lambs fed the WI diet consumed on average $45 \mathrm{~g} / \mathrm{d}$ (as fed basis) more, and had $+4 \%$ feed efficiency than lambs fed the NI diet. It is well recognized that factors other than chemical composition may affect animal performance, such as organoleptic characteristics of a forage or silage (Ball et al., 2001; Kung et al., 2018; McDonald et al., 1991). In our study, both untreated and inoculated corn silages had a desired fermentation, which resulted in suitable smell when the silos were opened. However, as inoculated silage had increased aerobic stability, this possibly affected odor and taste of silage. For instance, silages that are aerobically unstable may often present a moldy smell (Kung et al., 2018). A previous study reported that goats had higher preference for consuming corn silages with higher aerobic stability, which was possibly associated with better organoleptic characteristics of silage (Gerlach et al., 2013). Bacterial inoculation has been also found to improve organoleptic characteristics of silage. A study identified that inoculation of grass silage with $L$. plantarum changed the smell/taste of very sharp vinegar to sharp vinegar after $45 \mathrm{~d}$ of ensiling (Adesoji et al., 2010). Furthermore, in some cases where there are no obvious changes in silage composition and fermentation process, the increased animal performance has been attributed to a potential probiotic effect caused by silage inoculants (Contreras-Govea et al., 2013; Weinberg and Muck, 1996). Previous studies identified that Lactobacillus plantarum was able to survive in ruminal fluid (Contreras-Govea et al., 2013; Weinberg et al., 2003). Since bacteria contained in silage inoculants can survive in ruminal fluid, they can compete with other ruminal microorganisms by substrate, modifying the ruminal community in order to improve feed utilization (Weinberg et al., 2007). For instance, even with no great changes in silage fermentation, beef cattle and dairy 
Table 7

Sum of fatty acid profiles (\%) and enzymatic activities in the intramuscular fat of the longissimus muscle of lambs fed diets containing untreated corn silage (NI) or corn silage inoculated with Lactobacillus plantarum and Bacillus subtilis (WI) associated with (WA) or without (NA) amylolytic enzymes at feeding.

\begin{tabular}{|c|c|c|c|c|c|c|c|c|}
\hline \multirow{2}{*}{$\begin{array}{l}\text { Inoculation }^{\mathrm{a}} \\
\text { Enzyme }^{\mathrm{b}}\end{array}$} & \multicolumn{2}{|l|}{$\mathrm{NI}$} & \multicolumn{2}{|l|}{ WI } & \multirow[t]{2}{*}{ SEM } & \multicolumn{3}{|c|}{$P$-value ${ }^{\mathrm{c}}$} \\
\hline & NA & WA & NA & WA & & I & $\mathrm{E}$ & $\mathrm{I} \times \mathrm{E}$ \\
\hline SFA $^{d}$ & 45.4 & 47.0 & 47.6 & 47.6 & 0.325 & 0.035 & 0.18 & 0.18 \\
\hline UFA $^{\mathrm{e}}$ & 54.6 & 53.0 & 52.4 & 52.5 & 0.605 & 0.032 & 0.18 & 0.17 \\
\hline MUFA $^{\mathrm{f}}$ & 47.1 & 46.5 & 45.3 & 46.3 & 0.286 & 0.084 & 0.69 & 0.12 \\
\hline PUFA $^{g}$ & 7.52 & 6.50 & 7.19 & 6.74 & 0.234 & 0.93 & 0.13 & 0.55 \\
\hline UFA:SFA & 1.21 & 1.13 & 1.11 & 1.11 & 0.015 & 0.031 & 0.15 & 0.16 \\
\hline PUFA:SFA & 0.17 & 0.14 & 0.15 & 0.14 & 0.005 & 0.61 & 0.092 & 0.42 \\
\hline Omega-3 ( $\omega-3)$ & 0.30 & 0.27 & 0.30 & 0.34 & 0.013 & 0.22 & 0.79 & 0.19 \\
\hline Omega-6 ( $\omega-6)$ & 6.64 & 5.70 & 6.39 & 5.92 & 0.219 & 0.96 & 0.12 & 0.60 \\
\hline$\omega-6: \omega-3$ & 21.2 & 21.0 & 22.1 & 20.4 & 0.622 & 0.87 & 0.38 & 0.44 \\
\hline$\Delta^{9}$-desaturase (16) index ${ }^{\mathrm{h}}$ & 5.43 & 5.48 & 5.74 & 5.12 & 0.132 & 0.93 & 0.29 & 0.22 \\
\hline$\Delta^{9}$-desaturase (18) index ${ }^{\mathrm{i}}$ & 71.8 & 70.7 & 70.1 & 71.2 & 0.431 & 0.52 & 1.00 & 0.21 \\
\hline Elongase $^{j}$ & $68.6^{\mathrm{x}}$ & $67.9^{\mathrm{x}}$ & $66.6^{\mathrm{y}}$ & $68.0^{x}$ & 0.232 & 0.019 & 0.36 & 0.009 \\
\hline Atherogenicity $^{\mathrm{k}}$ & 0.34 & 0.35 & 0.37 & 0.35 & 0.005 & 0.19 & 0.54 & 0.12 \\
\hline Thrombogenicity $^{1}$ & 6.22 & 5.68 & 6.17 & 6.20 & 0.136 & 0.90 & 0.064 & 0.95 \\
\hline
\end{tabular}

${ }^{\mathrm{x}-\mathrm{y}}$ Means in the same row with different superscripts differed significantly $(P \leq 0.05)$.

${ }^{a}$ Whole-crop corn forage was treated at ensiling either with distilled water (2 L/t; untreated) or with Lactobacillus plantarum MA 18/5U at $1 \times 10^{5} \mathrm{cfu} / \mathrm{g}$ fresh forage (Lallemand Animal Nutrition, Goiânia, GO, Brazil) and Bacillus subtilis AT553098 at $1 \times 10^{5}$ cfu/g fresh forage (inoculated; Fatec Animal Nutrition and Health, Arujá, SP, Brazil).

${ }^{\mathrm{b}} \alpha$-amylase (602 DU/kg DM) was supplied to the wethers at total mixed ration delivery.

c $\mathrm{I}=$ inoculation; $\mathrm{E}=$ amylolytic enzymes; $\mathrm{I} \times \mathrm{E}=$ interaction between inoculation and amylolytic enzymes.

d SFA = saturated fatty acids (C10:0, C12:0, C14:0, C15:0, C16:0, C17:0, C18:0, and C20:0).

e UFA = unsaturated fatty acids (C14:1, C16:1, C17:1 cis-10, C18:1 n-9, C18:1 n-7, C18:2 n-6, C18:2 c9, t11, C18:3 n-6, C18:3 n-3, C20:1 n-9, C20:2, C20:3 n-6, C20:4 n-6, C20:5 n-5, C22:4 n-6, C24:1 n-9, and C22:6 n-3).

${ }^{\mathrm{f}}$ MUFA = monounsaturated fatty acids (C14:1, C16:1, C17:1 cis-10, C18:1 n-9, C18:1 n-7, C20:1 n-9, and C24:1 n-9).

g PUFA $=$ polyunsaturated fatty acids (C18:2 n-6, C18:2 c9, t11, C18:3 n-6, C18:3 n-3, C20:2, C20:3 n-6, C20:4 n-6, C20:5 n-3, C22:4 n-6, and C22:6 n-3).

h $\Delta^{9}$-desaturase $(16)$ index $=100 \times[(\mathrm{C} 16: 1$ cis-9)/(C16:1 cis-9 + C16:0) $]$.

i $\Delta^{9}$-desaturase $(18)$ index $=100 \times[(\mathrm{C} 18: 1$ cis-9)/(C18:1 cis-9 $+\mathrm{C} 18: 0)]$.

${ }^{\mathrm{j}}$ Elongase $=100 \times[(\mathrm{C} 18: 0+\mathrm{C} 18: 1$ cis9 $) /(\mathrm{C} 16: 0+\mathrm{C} 16: 1$ cis9 $+\mathrm{C} 18: 0+\mathrm{C} 18: 1$ cis9) $]$.

k Atherogenicity $=[(\mathrm{C} 12: 0+(4 \times \mathrm{C} 14: 0)+\mathrm{C} 16: 0)] / \mathrm{UFA}$.

1 Thrombogenicity $=[(\mathrm{C} 14: 0+\mathrm{C} 16: 0+\mathrm{C} 18: 0) /[(0.5 \times \Sigma$ MUFA $)+(0.5 \times \Sigma \omega 6+(3 \times \Sigma \omega 3)+(\Sigma \omega 3 / \Sigma \omega 6)]$.

cows fed diets with different crop silages inoculated with Lactobacillus plantarum had higher ADG and milk yield (Keady and Steen, 1994, 1995; Kung et al., 2003). However, the mechanism by which the bacteria contained in silage inoculants may improve animal performance through a probiotic effect is not totally understood and needs further investigation. Our findings are in agreement of those of McAllister et al. (1995), who reported no effect of inoculation on DMI, but the ADG of lambs fed barley silage diets increased following inoculation with Lactobacillus plantarum and Enterococcus faecium.

In contrast, dietary supplementation with amylolytic enzymes had no effects on DMI and ADG of lambs. Amylolytic enzymes are often used as a direct-fed additive to improve starch utilization in ruminants provisioned with high-grain diets (Nozière et al., 2014). However, in most cases in which it has been shown that enzyme supplementation improved DM, CP, and NDF digestibility, no benefits have been reported for DMI and ADG (Takiya et al., 2017; Weiss et al., 2011). Notably, the results from the literature regarding the effectiveness of amylolytic enzyme supplementation are highly inconsistent, and enhanced growth performance may not be expected in most cases. Furthermore, it is worth noting that the diets used in this study had increased total-tract starch digestibility ( $>$ 96\%) when fed to wethers (Lara et al., 2018). In this regard, it is unlikely that small improvements in starch digestibility caused by amylase supplementation may result in enhanced feed intake and growth performance. For instance, Rojo et al. (2005) did not report increases in DMI and ADG of lambs consuming diets with total-tract starch digestibility $\geq 95 \%$.

Despite the increased ADG of lambs fed the WI diet, carcass yield, carcass traits, and chemical composition of the meat were not affected by inoculation of corn silage. Changes in growth rate are not always accompanied by changes in protein and fat accretion efficiencies (NRC, 2007), and thus carcass and meat traits are expected to be similar. Moreover, Bacillus subtilis is able to grow anaerobically and to compete with other bacteria for substrate (e.g., Lactobacillus plantarum), but it has a very inefficient glucose fermentation pathway (McDonald et al., 1991; Nakano et al., 1997). In this regard, the few changes caused in fermentation process by silage inoculation might explain why carcass and meat traits were little affected. This is in agreement with the results of Basso et al. (2014), who reported higher ADG in lambs fed diets composed of corn silage inoculated with Lactobacillus buchneri alone or combined with Lactobacillus plantarum, but no changes in carcass traits. In addition, most studies that have focused on the effects of inoculation on carcass traits of small and large ruminants concluded that inoculation has little or no effect on carcass traits (Addah et al., 2014; Fugita et al., 2012; Rabelo et al., 2018); Lactobacillus buchneri, Lactobacillus casei, Lactobacillus plantarum, Enterococcus faecium, 
Pediococcus acidilactici, and Bacillus subtilis were the bacteria assessed in these studies.

Alterations in carcass and meat traits of lambs due to amylolytic enzyme supplementation are unlikely because of the lack of response of DMI and ADG. Moreover, extensive research over the years has failed to produce evidence that dietary supplementation with amylolytic enzymes has any effect on carcass traits of lambs (McAllister et al., 2000; Prado et al., 2015).

We detected an interaction effect between inoculation and enzyme supplementation for leg yield, in which leg yield was smaller in lambs fed the WI-WA diet than in lambs fed the NI-WA and WI-NA diets, but this effect was minor. Overall, commercial cuts were unaffected by any of the treatments applied in the current study, as reflected in the lack of response in carcass yield. Other meat traits, such as CL, WBSF, and color, were also unaffected by the treatments. Cuts from carcasses with longissimus WBSF values below $5 \mathrm{kgf}$, as was the case for the lambs included in our study (WBSF $\sim 3 \mathrm{kgf}$ ), are classified as tender (Tatum et al., 1999), which is noteworthy given that Pannier et al. (2014) reported that consumers tend to prefer more tender meat. With the exception of $b$ * (normal range of 3.30-11.1), the meat color of the lambs in the current study was within the normal range for $L^{*}(30.3-49.5)$ and $a^{*}(8.24-23.5$; Sañudo et al., 2008), which is easier to market. The lack of response in lamb meat traits to inoculation accords with our previous findings (Rabelo et al., 2016b), in which inoculation of corn silage with the bacterium Lactobacillus buchneri had no effect on the meat traits of finishing Nellore bulls.

Overall, inoculation and dietary supplementation with amylolytic enzymes had little effect on FFA. We noted an increase in the pentatonic acid concentration caused by inoculation, and enzyme supplementation reduced the concentrations of arachidonic and docosatetraenoic acid. Inoculation also slightly reduced oleic acid concentrations in lambs fed the NA diet but not in those receiving the WA diet. Oleic acid has beneficial impacts on meat health attributes by reducing concentrations of low-density lipoprotein (LDL) cholesterol and increasing the levels of high-density lipoprotein (HDL) cholesterol in the blood (Fugita et al., 2012). However, the slight reduction in oleic acid concentrations in lambs fed the WI-NA diet is unlikely to affect meat health properties. Moreover, alterations in meat FFA are often associated with changes in CLA proportions (Williams, 2000), which were not observed in the current study.

In comparison with the NI diet, inoculation of corn silage increased SFA from $46.2 \%$ to $47.6 \%$ and reduced UFA from $53.8 \%$ to $52.5 \%$ in longissimus muscle, and consequently the UFA:SFA ratio dropped from 1.17 to 1.11. Because the FA profiles of TMR used in this study were similar and DMI was unaffected by inoculation, factors other than dietary composition and intake level must have been responsible for the observed changes in UFA and SFA concentrations in meat, but what these factors may be are unknown. Studies have suggested that increasing SFA may result in increased cholesterol synthesis and thus favor LDL accumulation, which represents a risk factor for numerous cardiovascular disorders in humans (Madruga et al., 2008; Moloney et al., 2001). Nevertheless, despite being statistically significant, inoculation has only very minor effects on FA concentrations in meat, and because fat content was unchanged, it is likely that health-related properties of the meat were unaffected. Studies focusing on the effects of silage inoculation on FA composition of meat are scarce, but the results of the current study contrast with those reported by Rabelo et al. (2016b); in that study, the UFA:SFA ratio in the meat of finishing Nellore bulls fed a TMR composed of corn silage inoculated with $L$. buchneri was found to increase. However, this divergence in results may be due to differences in the animal species, age, physiology, and dietary composition used in the experiments. Thus, the mechanism(s) by which silage inoculation with Lactobacillus plantarum and Bacillus subtilis alter FA composition in the meat of lambs requires further investigation.

As mentioned, amylolytic enzymes are added to the diets of ruminants in order to improve starch utilization by livestock fed highgrain diets (Nozière et al., 2014). Ruminal degradation of amylose and amylopectin into compounds of lower molecular weights could increase total VFA concentrations, resulting in increased FA synthesis and subsequent modifications in the FA profiles of the meat due to changes in VFA molar proportion (Church, 1993). However, in our study with wethers (Lara et al., 2018), enzyme supplementation had no effect on total VFA concentrations, whereas propionate was altered by the interaction between inoculation and enzyme supplementation, and thus no clear patterns have emerged. This explains the lack of response of FA composition to enzyme supplementation.

Dietary supplementation with amylolytic enzymes increased the activity of elongase in lambs fed the WI diet but not in those fed the NI diet. Elongase is one component of a complex enzymatic system that plays an important role in polyunsaturated fatty acid (PUFA) formation in meat (Raes et al., 2004), but the minor change in elongase activity we observed here was insufficient to alter PUFA concentrations and the PUFA:SFA ratio. Despite the lack of response of the PUFA:SFA ratio to the various treatments, the overall mean ratio in our study (0.15) was lower than that (0.40) recommended by the British Health Department (1994), so that food may be beneficial to human health.

To the best of our knowledge, and taken together with the results of our corresponding research (Lara et al., 2018), the current study represents the first attempt to examine the interactions between inoculation of corn silage with Lactobacillus plantarum and Bacillus subtilis and dietary supplementation with amylolytic enzymes on lamb production. In summary, this study revealed a significant effect of silage inoculation on the growth performance of lambs as a consequence of higher ME intake, but without significant changes in meat quality. In contrast, dietary supplementation with amylolytic enzymes had no significant effects on lamb performance. For lamb production systems under feedlot conditions in which diets are composed of corn silage, the results of this study indicated that inclusion of the inoculant in the diet of lambs is an effective means of improving growth performance, whereas supplementation with amylolytic enzymes may be insufficient for improving lamb growth performance and meat quality.

\section{Conclusion}

Inoculation of corn silage with Lactobacillus plantarum and Bacillus subtilis enhanced growth performance of lambs with little effect on carcass and meat traits. In contrast, dietary supplementation with amylolytic enzymes and their interaction with inoculation did 
not have any effect on the growth performance and carcass and meat traits of lambs. Based on our results, we concluded that use of the silage inoculant examined in the present study improves lamb production at the farm scale, whereas amylolytic enzyme supplementation is not required under our experimental conditions.

\section{Conflict of interest}

The authors declare there is no conflict of interest.

\section{Acknowledgements}

This work was supported by the "Conselho Nacional de Desenvolvimento Científico e Tecnológico" (CNPq grant \#141008/20148). We thank Lallemand Animal Nutrition and Fatec Animal Nutrition and Health for providing the bacteria used in this study, and Nutreco and Alltech for providing the concentrate and $\alpha$-amylase, respectively.

\section{References}

Addah, W., Baah, J., Okine, E.K., Owens, F.N., McAllister, T.A., 2014. Effects of chop-length and a ferulic acid esterase-producing inoculant on fermentation and aerobic stability of barley silage, and growth performance of finishing feedlot steers. Anim. Feed Sci. Technol. 197, 34-46.

Adesoji, A.T., Ogunjobi, A.A., Fagade, O.E., Babayemi, O.J., 2010. Effect of Lactobacillus plantarum starter culture on the microbial succession, chemical composition, aerobic stability and acceptability by ruminant of fermented Panicum maximum grass. AU J. Tecnhol 14, 11-24.

Allen, M.S., 1996. Physical constraints on voluntary intake of forages by ruminants. J. Anim. Sci. 74, 3063-3075.

AOAC, 1996. Official Methods of Analysis, 16 ed. AOAC, Washington DC, USA.

Bach Knudsen, K.E., Eggum, B.O., Jacobsen, I., 1987. Nutritive-value of Danish-grown barley varieties. Carbohydrates and other major constituents. J. Cereal Sci. 6, 173-186.

Bal, M.A., Coors, J.G., Shaver, R.D., 1997. Impact of the maturity of corn for use as silage in the diets of dairy cows on intake, digestion, and milk production. J. Dairy Sci. 80, 2497-2503.

Ball, D., Collins, M., Lacefield, G., Martin, N., Mertens, D., Olson, K., Putnam, D., Undersander, D., Wolf, M., 2001. Understanding Forage Quality. American Farm Bureau Federation Publication, Park Ridge, IL, pp. 1-17.

Basso, F.C., Lara, E.C., Assis, F.B., Rabelo, C.H.S., Morelli, M., Reis, R.A., 2012. Características da fermentação e estabilidade aeróbia de silagens de milho inoculadas com Bacillus subtilis. Rev. Bras. Saúde Prod. Anim. 13, 1009-1019.

Basso, F.C., Adesogan, A.T., Lara, E.C., Rabelo, C.H.S., Berchielli, T.T., Teixeira, I.A.M.A., Siqueira, G.R., Reis, R.A., 2014. Effects of feeding corn silage inoculated with microbial additives on the ruminal fermentation, microbial protein yield, and growth performance of lambs. J. Anim. Sci. 92, 5640-5650.

Bergman, E.N., 1990. Energy contributions of volatile fatty acids from the gastrointestinal tract in various species. Physiol. Rev. 70, 567-590.

Bligh, E.G., Dyer, W.J., 1959. A rapid method of total lipid extraction and purification. Can. J. Biochem. Physiol. 37, 911-917.

Bolsen, K.K., Whitlock, L.A., Huck, G.L., Siefers, M.K., Schmidt, T.E., Pope, R.V., Uriarte, M.E., 2000. Effect of level of surface spoilage on the nutritive value of maize silage diets. Asian-Aus. J. Anim. Sci. 13, 121-122.

Brasil, Ministério da Agricultura, Pecuária e Abastecimento, Regulamento da Inspeção Industrial e Sanitária de Produtos de Origem Animal (Food of Animal Origin Sanitary and Industry Inspection), 1997, Brasília DF, Brazil.

Department of Health, 1994. Report on Health and Social Subjects No. 46. Nutritional Aspects of Cardiovascular Disease, Her Majesty's Stationery Office, London UK.

Cañeque, V., Sañudo, C., 2000. Metodologia para el estudo de la calidad de la canal y de la carne en rumiantes, Instituto Nacional de Investigación y Tecnología Agraria y Alimentaria (INIA), No. Q04 INIA 17174. Ministerio de Ciencia y Tecnología, Madrid, España.

Church, D.C., 1993. The Ruminant Animal: Digestive Physiology and Nutrition. Waveland Press, Long Grove IL, USA.

Conrad, H.R., Pratt, A.D., Hibbs, J.H., 1964. Regulation of feed intake in dairy cows. 1. Change in importance of physical and physiological factors with increasing digestibility. J. Dairy Sci. 47, 54-62.

Contreras-Govea, F.E., Muck, R.E., Broderick, G.A., Weimer, P.J., 2013. Lactobacillus plantarum effects on silage fermentation and in vitro microbial yield. Anim. Feed Sci. Technol. 179, 61-68.

FAO, Food and Agriculture Organization of the United Nations, 2015. Word Agriculture Towards 2015/2030: An FAO Perspective. FAO, London UK.

Food Chemicals Codex, 1996. Food Chemicals Codex, fourth ed. National Academies Press, Washington DC, USA.

Fugita, C.A., Prado, I.N., Jobim, C.C., Zawadzki, F., Valero, M.V., Pires, M.C.O., Prado, R.M., Françozo, M.C., 2012. Corn silage with and without enzyme-bacteria inoculants on performance, carcass characteristics and meat quality in feedlot finished crossbred bulls. Rev. Bras. Zootec. 41, $154-163$.

Furnols, M.F., Realini, C., Montossi, F., Sañudo, C., Campo, M.M., Oliver, M.A., Nute, G.R., Guerrero, L., 2011. Consumer's purchasing intention for lamb meat affected by country of origin, feeding system and meat price: a conjoint study in Spain, France and United Kingdom. Food Qual. Prefer. 22 , $443-451$.

Gerlach, K., Roß, F., Weiß, K., Büscher, W., Südekum, K.-H., 2013. Changes in maize silage fermentation products during aerobic deterioration and effects on dry matter intake by goats. Agric. Food Sci. 22, 168-181.

Greiner, S.P., Rouse, G.H., Wilson, D.E., Cundiff, L.V., Wheeler, T.L., 2003. Prediction of retail product weight and percentage using ultrasound and carcass measurements in beef cattle. J. Anim. Sci. 81, 1736-1742.

Hamm, R., 1986. Functional properties of the myofibrillar system and their measurements. In: Bechtel, P.J. (Ed.), Muscle As Food. Academic Press Inc., New York, USA, pp. 135-199.

Honikel, K.O., Hamm, R., 1994. Measurement of water-holding capacity and juiciness. In: Pearson, A.M., Dutson, T.R. (Eds.), Quality Attributes and their Measurement in Meat, Poultry and Fish Products. Springer, Boston MA, USA, pp. 125-161.

Ingle, D.L., Bauman, D.E., Garrigus, U.S., 1972. Lipogenesis in the ruminant: in vivo site of fatty acid synthesis in sheep. J. Nut. 102, 617-623.

ISO, 1978. International Organization for Standardization, Method ISO 5509. ISO, Geneva, Switzerland.

Jaeger, T.F., 2008. Categorical data analysis: away from ANOVAs (transformation or not) and towards logit mixed models. J. Mem. Lang. 59, 434-446.

Keady, T.W.J., Steen, W.J., 1994. Effects of treating low dry matter grass with a bacterial inoculant on the intake and performance of beef cattle and studies on its mode of action. Grass Forage Sci. 49, 438-446.

Keady, T.W.J., Steen, W.J., 1995. The effects of treating low dry matter, low digestibility grass with a bacterial inoculant on the intake and performance of beef cattle and studies on its mode of action. Grass Forage Sci. 50, 217-226.

Kotarski, S.F., Waniska, R.D., Thurn, K.K., 1992. Starch hydrolysis by the ruminal microflora. J. Nut. 122, $178-190$.

Kung Jr., L., Stokes, M.R., Lin, C.J., 2003. Silage additives. In: Buxton, D.R., Muck, R.E., Harrison, J.H. (Eds.), Silage Science and Technology. American Society of Agronomy, Madison WI, USA, pp. 305-360.

Kung Jr., L., Shaver, R.D., Grant, R.J., Schmidt, R.J., 2018. Silage review: interpretation of chemical, microbial, and organoleptic components of silages. J. Dairy Sci. 101, 4020-4033.

Lage, J.F., Berchielli, T.T., San Vito, E., Silva, R.A., Ribeiro, A.F., Reis, R.A., Dallantonia, E.E., Simonetti, L.R., Delevatti, L.M., Machado, M., 2014. Fatty acid profile, carcass and meat quality traits of young Nellore bulls fed crude glycerin replacing energy sources in the concentrate. Meat Sci. $96,1158-1164$. 
Lara, E.C., Basso, F.C., Assis, F.B., Souza, F.A., Berchielli, T.T., Reis, R.A., 2016. Changes in the nutritive value and aerobic stability of corn silages inoculated with Bacillus subtilis alone or combined with Lactobacillus plantarum. Anim. Prod. Sci. 56, 1867-1874.

Lara, E.C., Bragiato, U.C., Rabelo, C.H.S., Messana, J.D., Reis, R.A., 2018. Inoculation of corn silage with Lactobacillus plantarum and Bacillus subtilis associated with amylolytic enzyme supply at feeding. 1. Feed intake, apparent digestibility, and microbial protein synthesis in wethers. Anim. Feed Sci. Technol. 243, 22-34.

Madruga, M.S., Vieira, T.R.L., Cunha, M.G.G., Filho, J.M.P., Queiroga, R.C.R.E., Sousa, W.H., 2008. Efeito de dietas com níveis crescentes de caroço de algodão integral sobre a composição química e o perfil de ácidos graxos da carne de cordeiros Santa Inês. Rev. Bras. Zootec. 37, $1496-1502$.

McAllister, T.A., Selinger, L.B., McMahon, L.R., Bae, H.D., Lysyk, T.J., Oosting, S.J.-, Cheng, K.-J., 1995. Intake, digestibility and aerobic stability of barley silage inoculated with mixtures of Lactobacillus plantarum and Enterococcus faecium. Can. J. Anim. Sci. 75, 425-432.

McAllister, T.A., Stanford, K., Bae, H.D., Treacher, R.J., Hristov, A.N., Baah, J., Shelford, J.A., Cheng, K.-J., 2000. Effect of a surfactant and exogenous enzymes on digestibility of feed and on growth performance and carcass traits of lambs. Can. J. Anim. Sci. 80, 35-44.

McDonald, P., Henderson, A.R., Heron, S.J.E., 1991. The Biochemistry of Silage, 2nd ed. Chalcombe Publications, Aberystwyth, UK.

Mertens, D.R., 2002. Gravimetric determination of amylase treated neutral detergent fiber in feeds with refluxing in beakers or crucibles: collaborative study. J. AOAC Int. $85,1212-1240$.

Moloney, A.P., Mooney, M.T., Kerry, J.P., Troy, D.J., 2001. Producing tender and flavor some beef with enhanced nutritional characteristics. Proc. Nut. Soc. 60, $221-229$.

Moran, J.P., Weinberg, Z.G., Ashbell, G., Hen, Y., Owen, T.R., 1996. A comparison of two methods for the evaluation of the aerobic stability of whole crop wheat silage. In: Proceedings of the 11th International Silage Conference. University of Wales; Aberystwyth, UK. pp. $162-163$.

Nakano, M.M., Dailly, Y.P., Zuber, P., Clark, D.P., 1997. Characterization of anaerobic fermentative growth of Bacillus subtilis: identification of fermentation end products and genes required for growth. J. Bacteriol. 179, 6749-6755.

Noziére, P., Steinberg, W., Silberberg, M., Morgavi, D.P., 2014. Amylase addition increases starch ruminal digestion in first-lactation cows fed high and low starch diets. J. Dairy Sci. 97, 2319-2328.

NRC, 1985. Nutrient Requirements of Sheep. Natl. Acad. Press, Washington, DC, USA.

NRC, 2007. Nutrient Requirements of Small Ruminants: Sheep, Goats, Cervids, and New World Camelids. Natl. Acad. Press, Washington, DC, USA.

Oliveira, C.A., Millen, D.D., 2014. Survey of the nutritional recommendations and management practices adopted by feedlot cattle nutritionists in Brazil. Anim. Feed Sci. Technol. 197, 64-75.

Oliveira, A.S., Weinberg, Z.G., Ogunade, I.M., Cervantes, A.A.P., Arriola, K.G., Jiang, Y., Kim, D., Li, X., Gonçalves, M.C.M., Vyas, D., Adesogan, A.T., 2017. Metaanalysis of effects of inoculation with homofermentative and facultative heterofermentative lactic acid bacteria on silage fermentation, aerobic stability, and the performance of dairy cows. J. Dairy Sci. 100, 4587-4603.

Pannier, L., Gardner, G.E., Pearce, K.L., McDonagh, M., Ball, A.J., Jacob, R.H., Pethick, D.W., 2014. Associations of sire estimated breeding values and objective meat quality measurements with sensory scores in Australian lamb. Meat Sci. 96, 1076-1087.

Pereira, M.N., Von Pinho, R.G., Bruno, R.G.S., Calestine, G.A., 2004. Ruminal degradability of hard or soft texture corn grain at three maturity stages. Sci. Agric. 61, 358-363.

Philippeau, C., Michalet-Doreau, B., 1997. Influence of genotype and stage of maturity of maize on rate of ruminal starch degradation. Anim. Feed Sci. Technol. 68, $25-35$.

Prado, T.F., França, A.F.S., Meirinhos, M.L.G., Peron, H.J.M.C., Ferreira, R.N., Oliveira, L.G., Correa, D.S., 2015. Animal performance and carcass characteristics from confined lambs fed on concentrate feed additives. An. Acad. Bras. Ciênc. 87, 2255-2263.

Rabelo, C.H.S., Mari, L.J., Reis, R.A., 2016a. Survey about the use of bacterial inoculants in Brazil: effects on silage quality and animal performance. In: Silva, T., Santos, E.M. (Eds.), Advances in Silage Production and Utilization. InTech, Rijeka, Croatia, pp. 3-37.

Rabelo, C.H.S., Basso, F.C., McAllister, T.A., Lage, J.F., Gonçalves, G.S., Lara, E.C., Oliveira, A.A., Berchielli, T.T., Reis, R.A., 2016b. Influence of Lactobacillus buchneri as silage additive and forage:concentrate ratio on the growth performance, fatty acid profile in longissimus muscle and meat quality of beef cattle. Can. J. Anim. Sci. 96, 550-562.

Rabelo, C.H.S., Vallente, A.L.S., Barbero, R.P., Basso, F.C., Reis, R.A., 2018. Performance of finishing beef cattle fed diets containing maize silages inoculated with lactic-acid bacteria and Bacillus subtilis. Anim. Prod. Sci. https://doi.org/10.1071/AN16358.

Rojo, R., Mendoza, G.D., Gonzalez, S.S., Landois, L., Barcena, R., Crosby, M.M., 2005. Effects of exogenous amylases from Bacillus licheniformis and Aspergillus niger on ruminal starch digestion and lamb performance. Anim. Feed Sci. Technol. 124, 655-665.

Raes, K., De Smet, S., Demeyer, D., 2004. Effect of dietary fatty acids on incorporation of long chain polyunsaturated fatty acids and conjugated linoleic acid in lamb, beef and pork meat: a review. Anim. Feed Sci. Technol. 113, 119-221.

Sañudo, C., Arribas, M.M.C., Silva Sobrinho, A.G., Silva Sobrinho, A.G., Sañudo, C., Osório, J.C.S., Arribas, M.M.C., Osório, M.T.M., 2008. Qualidade da carcaça e da carne ovina e seus fatores determinantes. Producão de Carne Ovina. FUNEP, Jaboticabal, Brazil, pp. 171-228.

Scollan, N., Hocquette, J.-F., Nuernberg, K., Dannenberger, D., Richardson, I., Moloney, A., 2006. Innovations in beef production systems that enhance the nutritional and health value of beef lipids and their relationship with meat quality. Meat Sci. 74, 17-33.

Takiya, C.S., Calomeni, G.D., Silva, T.H., Vendramini, T.H.A., Silva, G.G., Consentini, C.E.C., Bertoni, J.C., Zilio, E.M.C., Rennó, F.P., 2017. Increasing dietary doses of an Aspergillus oryzae extract with alpha-amylase activity on nutrient digestibility and ruminal fermentation of lactating dairy cows. Anim. Feed Sci. Technol. 228, $159-167$.

Tatum, J.D., Smith, G.C., Belk, K.E., 1999. New approaches for improving tenderness, quality and consistency of beef. In: Proceedings of the Animal Society of Animal Science. Indianapolis, USA. pp. 1-10.

Tricarico, J.M., Johnston, J.D., Dawson, K., 2008. Dietary supplementation of ruminant diets with an Aspergillus oryzae $\alpha$-amylase. Anim. Feed Sci. Technol. 145, $136-150$.

Weinberg, Z.G., Muck, R.E., 1996. New trends and opportunities in the development and use of inoculants for silage. FEMS Microbiol. Rev. 19, 53-68.

Weinberg, Z.G., Muck, R.E., Weimer, P.J., 2003. The survival of silage inoculant lactic acid bacteria in rumen fluid. J. Appl. Microbiol. 94, 1066-1071.

Weinberg, Z.G., Shatz, O., Chen, Y., Yosef, E., Nikbahat, M., Ben-Ghedalia, D., Miron, J., 2007. Effect of lactic acid bacteria inoculants on in vitro digestibility of wheat and corn silages. J. Dairy Sci. 90, 4754-4762.

Weiss, W.P., Steinberg, W., Engstrom, M.A., 2011. Milk production and nutrient digestibility by dairy cows when fed exogenous amylase with coarsely ground dry corn. J. Dairy Sci. 94, 2492-2499.

Wheeler, T.L., Koohmaraie, M., Schackelford, S.D., 1995. Shear Force Procedures for Meat Tenderness Measurement, Roman L. Hruska US Marc USDA. Clay Center.

Williams, C.M., 2000. Dietary fatty acids and human health. Ann. Zootech. 49, 165-180.

Woolford, M.K., 1990. The detrimental effects of air on silage. J. Appl. Bacteriol. 68, 101-116.

Zuber, P., Nakano, M.M., Marahiel, M.A., 1993. Peptide antibiotics. In: Sonenshein, A.L., Hoch, J.A., Losick, R. (Eds.), Bacillus subtilis and Other Gram-Positive Bacteria: Biochemistry, Physiology, and Molecular Genetics. American Society for Microbiology, Washington DC, USA, pp. 897-916. 